\title{
Cultural Politics Then and Now
}

\author{
Kent Worcester, \\ Marymount Manhattan College
}

James Doyle, Progressive Heritage: The Evolution of a Politically Radical Literary Tradition in Canada (Waterloo: Wilfrid Laurier University Press, 2002).

Kevin Mattson, Intellectuals in Action: The Origins of the New Left and Radical Liberalism, 1945-1970 (University Park: Penn State University Press, 2002).

John McGowan, Democracy's Children: Intellectuals and the Rise of Cultural Politics (Ithaca: Cornell University Press, 2002).

Alan M. Wald, Exiles From a Future Time: The Forging of the Mid-Twentieth Century Literary Left (Chapel Hill: University of North Carolina Press, 2002).

The books under review are concerned with different aspects of North American left-wing culture and politics. James Doyle and Alan Wald are primarily interested in the impact of the Communist Party on creative writers and artists in the 1930s and 1940s. Although they tackle different national cases, Doyle and Wald canvas many of the same themes and their books are broadly complementary. Both texts are grounded in extensive archival and biographical research, and both authors are keen to present Communism's relationship to the world of letters as more complex, productive, extensive, and less easily stereotyped than has been generally recognized.

Kevin Mattson's well-received study of the intellectual origins of the early New Left is similarly rooted in archival research and primary sources. His book focuses on the ideas and activities of a small coterie of intellectuals $-\mathrm{C}$. Wright Mills, Paul Goodman, William Appleman Williams, and Arnold Kaufman - who straddled the boundaries between liberalism and radicalism. Rather than focusing on the pro-Communist left, Mattson identifies 1940s anti-Stalinism, as represented by such figures as Dwight Macdonald and Daniel Bell, as a key influence on Mills and Goodman in particular. In his penultimate chapter Mattson shifts from individuals to journals, sketching the intellectual history of Studies on the Left and New University Thought. Here Mattson might usefully have incorporated the pro-Communist left into his narrative - the Popular Front surely meant more to James Weinstein, Eleanor Hakim, and other editors of Studies on the Left than the Moscow Trials, for reasons that bear thinking about - but Mattson mainly interprets these publications as a means by which radicalized 
graduate students and junior faculty could reconcile their scholarship with political activism.

Of the four books only John McGowan's Democracy's Children pays any serious attention to non-left intellectuals, or intellectuals from outside Canada or the United States. At the same time, his book belongs in the category of literary theory (with an admirably light touch, it should be said) rather than intellectual history. I do not know if it is 'easier' to produce light-hearted, theoryminded essays than densely footnoted intellectual histories, but it seems unlikely McGowan has put in quite as many hours in the stacks as, say, Alan Wald, who admits his family gave up "most of our vacation time for many years" (393). McGowan is less interested in identifying a 'recoverable past' than the others, who write in hopes of inspiring and instructing future generations of radicals. Paradoxically, McGowan is probably the most sanguine regarding the present condition of both literary culture and the left.

James Doyle, a professor emeritus of English at Wilfrid Laurier University, describes his "main interest" as "the achievements of writers connected or sympathetic to the Communist Party of Canada" (13). He approaches this topic on a chronological basis, tracing the influence of Communism on creative writers from the 1920s to the 1980s, with a special emphasis on the 1930s-1940s, the high water mark of the Party's national influence. Like Alan Wald, he pays particular attention to life stories that have been overlooked by intellectual and literary historians. "Besides all the formal and ideological aspects of this subject," writes Doyle, "I am interested in the human side of it, by which I mean the words, actions, beliefs, and artistic achievements of the individual people who were involved.... The Canadian literary artists who wrote from a Communist perspective were indeed human - complete with the eccentricities, conventionalities, hypocrisies, and capacity for imagination and artistic expression that characterize the species" (12).

Doyle identifies a number of nineteenth-century writers as contributing to "the progressive heritage in Canadian literature." They include William Lyon Mackenzie, a crusading journalist in the tradition of William Cobbett and Thomas Paine, and Thomas MacQueen, a poet and writer who criticized colonialism, the factory system, and the Catholic Church. Their unselfconscious invocation of "the people" located them in or alongside a lyric folk tradition of ballads, sea shanties, and poetry that expressed "strong feelings of communal pride, defiance of arbitrary and exploitative authority, and rebellious or revolutionary political sentiments" (26). Fiction writers such as Colin McKay and Bertrand Sinclair, who wrote knowingly about fishermen, farmers, and sailors in the early 20th century, were also part of this indigenous folk culture. Like Mackenzie and MacQueen their contributions went largely unrecognized by an Anglophilic, urban-centric literary establishment.

In the 1920s and 1930s intellectuals in and around the Communist Party of 
Canada (CPC) began to claim writers like Mackenzie and McKay as part of a distinctive, and more or less cohesive, Canadian progressive culture. Starting in the 1940s Margaret Fairley actively publicized and anthologized the poems and stories of earlier generations of radical writers. Her efforts reflected the notion that only the Party could reconcile authentic local traditions with the class struggle and the science of Marxist-Leninism. Crudely put, if a line of continuity could be established between literary Communism and earlier literary movements then the Party's leadership in the field of arts and letters could be secured. As Doyle notes, Fairley "strove to relate her intense loyalty to Canada to her understanding of Marxist internationalism" (56).

Most writers and intellectuals around the party concentrated on producing new work rather than synthesizing and analyzing different literary traditions. Measured in commercial terms two of the most successful figures were Joseph Sylvester Wallace and Dyson Carter. The son of a travelling salesman, Joe Wallace contributed "poems, news items, and editorials" (68) to the party press starting in the early 1920 s while launching a parallel career in advertising. In 1941 Wallace was interned with other CPC leaders by the Canadian government under the War Measures Act. Two years later, several months after his release, his first book of poems, Night is Ended, appeared to laudatory reviews. A Catholic as well as a party member, Wallace wrote on a wide range of topics, including his Marxist spirituality: "St. Thomas More (to prove my point/I bring two famous men in)/Utopia's author, now anoint,/Would be at home with Lenin" (164).

Although Doyle seems somewhat more comfortable with biography and history than close textual analysis, his brief discussion of Night is Ended makes a credible case for Joe Wallace as a poet rather than simply an illustrative figure from the Communist past. By the 1950s, however, Wallace's poems were receiving more attention in the Soviet bloc than in his native homeland. One literary historian subsequently described him as Canada's "only consistently dedicated and genuinely proletarian poet," but Wallace himself complained that he was "unappreciated in Canada, even within the Communist community" (253). Yet he "maintained his Party membership and continued to write militant poetry expressing his faith in the coming revolution until his death at age eighty-five in a Vancouver nursing home in 1975," (262) Doyle reports.

H. Dyson Carter was the son of Salvation Army officers who suffered from osteogenesis imperfecta, "an incurable hereditary disease that makes bones brittle and inclined to break easily, especially in childhood" (174). He trained as a physical chemist and later worked as a consulting chemical engineer. He also wrote short fiction and novels, as well as "pseudonymous pot-boilers," (225) and published in the pulp magazine Argosy as well as various Canadian and U.S. Communist publications. Some of his fiction was autobiographical, while other works imported social themes into sub-literary genres. In 1942 he began gen- 
erating radio scripts for the Canadian Broadcasting Corporation on science and technology. "By the end of the war he was a modestly successful novelist, a popular science journalist eagerly read across Canada, and a well-known publicist for the achievements of the USSR in war, science, and technology"(178-179). For years Carter maintained a personal mail-order service, churning out books, pamphlets, and magazines on different aspects of science, medicine, and the Soviet Union. "Stalin is a scientist," he once wrote, "Making socialism is a science. The whole Soviet Union is science applied to human life" (261). He almost certainly experienced the disintegration of the Soviet system, which came at the very end of his life, as an unspeakable abomination.

Doyle's account leaves ample room for dogmatists like Dyson Carter and romantics like Joe Wallace, not that these categories are necessarily exclusive. But his survey excludes anarchists, Trotskyists, and independent radicals who doubted the promises Communists made on behalf of the Soviet Union and rejected the Party's presumption of working-class leadership. One of the few novels he mentions that criticized the party and its leaders was Earle Birney's Down the Long Table (1955), which offered "a fictionalization of one Canadian's journey from political naivete, through Stalinism and Trotskyism, to disillusionment" (233). One party intellectual called it "an evil thing," and Doyle himself dismisses the novel as fallout from "the bourgeois literary community" (235). But judging from Doyle's summary the book has all the makings of a juicy roman-à-clef.

Non-Communist radicals receive only marginally more attention in Alan Wald's Exiles from a Future Time, which, like Progressive Heritage, focuses almost exclusively on what Wald terms the "Conmunist-led tradition" (xii). Like Doyle, Wald locates mid-century Communists as central actors in the major artistic and cultural movements of their day. Neither pays significant attention to Communism's many left-wing critics, although both identify the rise of the New Left in the 1960s as the key challenge to Communism as a cultural and intellectual force. Wald, who is a professor of English at the University of Michigan in Ann Arbor, promises to return to the Communist-led literary tradition in two subsequent volumes, including one dealing with Communism and mass culture.

The near exclusion of non-Communist voices from Exiles from a Future Time is somewhat surprising, given Wald's deserved reputation as one of the major literary historians of Trotskyism and anti-Stalinism. But his essays and reviews over the past ten years, in Against the Current and elsewhere, have made his burgeoning interest in developments on the other side of left-wing ideology's Great Divide abundantly clear. Traces of Wald's earlier sensibility may be found in this new work, such as when, in the concluding pages, he concedes that the call for writers to immerse themselves in the working class movement was "too often a euphemism for carrying out Communist Party policies" (318). But for 
the most part Wald eschews any direct criticism of the party, or party leaders, preferring to emphasize the richness of individual contributions and the profuse diversity of talent that the U.S. Communists attracted during their mid-century heyday.

Wald opens his study with Guy Endore, a novelist and screenwriter who managed to combine a fierce attachment to Soviet-style Communism with an attractively eccentric lifestyle. "Politically," Wald admits, "Endore was what historians of the Literary Left would regard as an orthodox "Stalinist"' (1). The author of The Werewolf in Paris (1933), a best-selling horror classic, as well as mysteries, biographies, and filmed screenplays, Endore was a devotee of Yoga, a militant anti-vivisectionist, and a fan of theosophy. Yet he dismissed concerns about the Soviet purges and defended the Hitler-Stalin pact. After breaking with the party, Endore remained loyal to Communist ideals, which he sought to apply through Synanon, the drug rehabilitation center and utopian community he helped found in the late 1950s. Wald comments: "Endore's career as a novelist, which continued long after the Depression, is as legitimate a part of the Communist Literary Left as were the careers of [Mike] Gold and [Jack] Conroy. Yet nowhere are achievements such as Endore's featured in studies of Left-wing fiction" (6).

Guy Endore was by no means the only creative personality who prized both Stalin and his individual muse. Joy Davidman, who penned award-winning poetry, as well as novels and screenplays, was active in the League of American Writers and served as the poetry critic at the New Masses. After converting from Marxism to Christianity in the early 1950s she corresponded with, and later married, the English writer C.S. Lewis. (Their courtship was dramatized by Debra Winger and Anthony Hopkins in the 1992 film Shadowlands.) Wald makes a strong case for Davidman's creative presence, not only as a poet but as an editor and critic. Like Endore, she proved it was possible to be a dedicated Communist while pursuing a personal vision - although the fact that neither occupied top positions in the party's cultural apparatus, and eventually dropped out of the party, is also noteworthy. In all, Wald identifies several dozen creative figures - not only poets and novelists but short story writers, playwrights, and screenwriters - whose Communist idealism went hand-in-hand with some real measure of artistic generativity.

Wald is especially attuned to poetry, which he plausibly argues has been overlooked by historians of literary radicalism. In his 1983 study of the poets John Wheelwright and Sherry Mangan, The Revolutionary Imagination, Wald demonstrated a gift for reading political verse with insight and sensitivity. Here he resuscitates the poetry of a succession of working-class, African-American, and proto-feminist writers whose lines appeared in places like Dynamo, The Anvil, The New Masses, and Negro Story. A handful of these poets, such as Muriel Rukeyser, Sterling Brown, and Kenneth Fearing, are reasonably well 
known, but others have fallen down history's memory-hole. His chapter on "Three Moderns" zeroes in on Herman Spector, Sol Funaroff, and Alfred Hayes, three pro-Communist poets whose work reflected modernist impulses that the party hierarchy actively disdained. Wald's substantial selections, along with his informative commentary, confirm his assertion that "a strong current within the Communist cultural movement embraced many features of modernism and the avant-garde" (226). The notion that 1930s-1940s Communist cultural politics was exclusively populist and anti-modernist fails to capture the extent to which some Communists strayed beyond the party's literary doctrines.

Wald's account suggests that many of the country's best known AfricanAmerican writers, including Claude McKay, Langston Hughes, Richard Wright, and Ralph Ellison, were each more deeply influenced by and involved in Communist literary activities than has been broadly acknowledged. Ellison's radical literary criticism from the late 1930 s, for example, has been almost completely disregarded. "Scarcely a major African American writer of the interwar years, and especially the poets, was unaffected by Marxism," (294) Wald concludes.

Yet Black Marxists such as McKay and Hughes, Wald acknowledges, in an unusually blunt passage, "were compromised by faith placed in two allies" first, the Soviet Union, with its claim of having attained absolute social equality, and second, "the utopian hope for white working-class allies" (294). "The experience of national and racial oppression was vivid, real, and overwhelming for Black writers," he notes. "Full-blown interracial class solidarity was by comparison almost a leap forward to a quixotic chimera" (295). "Premature socialist feminists," (252) like Meridel Le Sueur, faced analogous difficulties in conveying and asserting the specificity of group experience in the context of orthodox Communism's characteristic emphasis on working-class unity and solidarity. If anything, the complexities and dilemmas of race and race relations received far more attention from party intellectuals and writers than the social condition of women. As Wald explains, "pro-Communist women writers were part of a political movement that devoted only limited theoretical attention to the origins and dynamics of women's oppression" (252).

Wald's claim that individual Communists crafted serious poems, plays, stories, and so on is a convincing one, as is his suggestion that black and female Communists dealt with themes and tropes that assumed renewed urgency in the wake of the social movements of the 1960s. Party membership nevertheless imposed certain constraints on artistic and intellectual expression. Wald seems reluctant to admit this, but his research has turned up plenty of evidence for it. This is not simply a question of the intense hatred that the party poured over anything that smacked of Trotskyism and other political heresies, but was apparent in the inherently sectarian quality of party life, even in the era of the Popular Front. The party's internal culture favored order-giving, and order-taking, over 
dissension. Party leaders, even those assigned to sensitive cultural arenas, were used to having their instructions carried out. Members who stepped out of line or crossed the wrong person might find themselves summarily ostracized, penalized, interrogated, or expelled. Communist discourse offered a rich vocabulary of denunciation. It hardly seems accidental that some of Wald's artistic favorites ended up depressed, suicidal, or alcoholic, although the extraordinary harassment that known Communists experienced in different settings also undoubtedly contributed to whatever emotional and personal crises party members and exmembers went through.

Wald acknowledges the existence of "commissars" but his treatment of major players like Michael Gold, V.J. Jerome, A.B. Magil, and Alexander Trachtenberg is rather tender. Rather than concentrating on their mastery of hard polemics, he emphasizes their individual artistic ambitions. Thus, Mike Gold "really cared about socialism more than he cared about his personal career," and was therefore unable to produce a follow-up worthy of his novel Jews Without Money (1930). V.J. Jerome was "an equally severe critic of his own writing" (174) as everyone else's. A.B. Magil nursed ambitions as a writer but "had the aura of being 'the party whip'." As director of International Publishers, Alexander Trachtenberg put together a strong list of working-class fiction, and in so doing "discharged outstanding services to literature in the United States," (79) according to Wald. But Gold's style of criticism was often indistinguishable from slander, and Jerome, Magil, and Trachtenberg were each fully capable of hammering the party line into the ground regardless of the policy in question or whether it had been policy the week before. Wald lists the working-class novels International Publishers issued under Trachtenberg's leadership but I am newly curious about the political and philosophical titles that appeared under this "outstanding" editorial regime.

Little evidence of the party's decades-long interventions in the spheres of culture, the arts, and ideas turns up in Kevin Mattson's book, which champions a different breed and generation of intellectual from the flinty early-twentiethcentury personalities that Alan Wald recovers and mostly celebrates. Mattson, an associate professor of History at Ohio University, argues that the Communist Party's most formidable critics, the New York anti-Stalinist intellectuals, provided some of the main ingredients that went into the early New Left. AntiStalinists raised valid points about the dangers of authoritarianism, and for the most part kept a wary distance from consumer society. Even Daniel Bell, who was by no means the most militant of the New York Intellectuals, posed awkward questions about capitalist forms of alienation at the workplace and in the community. And Irving Howe, who later generated some "alienation" of his own - on the part of New Left activists - used the pages of Dissent in the mid-to-late 1950 s to challenge the prevailing conformity of the age.

Mattson's attitude toward the anti-Stalinist paradigm is hardly complemen- 
tary, however. He admires certain aspects of Dwight Macdonald's political trajectory, for example, including his break with Marxism and his embrace of native forms of radicalism, such as religiously motivated pacifism, and nineteenth century utopianism. But he bemoans the fact that Macdonald's antiStalinism "hardened" in the late 1940s and that he "went so far as to equate Stalin with Hitler." "More and more," Mattson complains, "Macdonald made an issue of Stalin, arguing that he had underplayed the dictator's significance before" (37). (For Macdonald, of course, more was at stake than Stalin's "significance.") For Mattson, New York's entire political culture was warped by the "sectarianism" of the Stalin-Trotsky fight, and he approvingly cites Eleanor Hakim's smug observation that Studies on the Left "could never have originated on either the east or west coast where there are so many splits and factions most of which are at least 25 years behind the times" (231).

Mattson's reading of C. Wright Mills and Paul Goodman, both of whom distanced themselves from the anti-Stalinist camp and came close to adopting an anti-anti-Communist position, is rather more nuanced than his treatment of the Old Left. While Mills' dual career as a 1950s rebel and best-selling sociologist continues to generate significant interest on the part of biographers as well as social scientists, Goodman's star has fallen and it is nice to see his writings receive some of the attention and scrutiny they deserve. Mattson locates Goodman as an authentically American pragmatist who grounded his "radical visions in psychological theory" (102). He ties Goodman's Growing Up Absurd (1960) to his critique of counter-cultural rebellion and his longstanding interest in urban and political reform. Yet he also notes that the proposals Goodman "made in the name of practicality seemed impractical." Like C. Wright Mills, "he sometimes dismissed liberalism and sometimes saw the good in it" (143). Goodman's ability to fuse political analysis, social criticism, and critical selfreflection did not keep him from committing errors in judgement, but Mattson is rightly enamored with Goodman's undiminished aura of integrity and independence.

While Mills was never entirely happy working within the confines of the research university, and Goodman largely operated outside of formal institutions, both William Appleman Williams and Arnold Kaufman managed to function as public intellectuals even as they hewed to the canons of professional responsibility. They were also cultural mid-westerners who owed less to New York intellectualism than either Mills or Goodman. At the same time, of "all the thinkers studied here," Mattson states, "Williams was the most comfortable declaring himself an outright socialist" (168). More specifically, he was a Christian socialist who urged anti-Vietnam war activists to "'speak American' that is, appeal to American values even while criticizing America's actions abroad" (178). Williams, along with Goodman and Kaufman in the late 1960s, and Mills a decade earlier, was challenged to find ways to communicate his 
ideas and values to the new radicals. None of them seem to have found this work particularly easy.

Arnold Kaufman, who helped plan and lead the earliest anti-war teach-ins, shared Williams' concern that campus activists might seal themselves off from the wider community and prove "incapable of transforming American politics" (204). From the standpoint of both Williams and Kaufman, the politics of radical reformism promised a brighter future for progressives and leftists than either revolutionary party-building or utopian community-building. Both talked up the continued validity and radical potentiality of America's founding ideals. Their specific intellectual ambitions were quite different, however; Williams' major contributions were in the area of U.S. diplomatic history, and the history of the American empire, while Kaufman sought, in the manner of a political theorist, to self-consciously synthesize the best of the liberal and radical traditions.

Kaufman's book, The Radical Liberal: New Man in American Politics (1968), which originally appeared as an entire issue of Dissent, ambitiously sought to reconcile the doctrines of James Madison and Jean-Jacques Rousseau. Kaufman was especially sympathetic toward liberals who wrote after Marx, such as Leonard Hobhouse and John Dewey, who recognized the persistence and saliency of socioeconomic forms of inequality. According to Mattson, Kaufman provided nothing less than "a political and philosophical vision for the New Left - one that matched participatory democracy with larger structures capable of protecting individual rights and social justice" (226). Any underlying philosophical or political tension "between radicalism and liberalism might not have needed to exist," (227) Mattson bravely speculates, had Kaufman's message of participatory democracy in tandem with liberal institutions been sufficiently absorbed by the New Left. Kaufman's reworking of liberal and radical motifs was cut short when he died in an airplane crash in 1971. He was a "casualty of America's military: an Air Force pilot had flown off course, and after he ejected, his plane collided into the passenger plane on which Kaufman was traveling" (225).

The appeal of Amold Kaufman's pragmatism, pluralism, and radical(ized) liberalism would not be lost on John McGowan, who positively yearns to detach the left from its Marxist and Communist residues. A "post-Communist left," he says, is "beginning to relearn the resources that [liberal or representative] democracy affords" (7). At a time when "the intellectual and her peers almost invariably hold university posts" - or so McGowan claims - a new cultural left has emerged. This higher ed-based left recognizes "the traditional formulas of the "old Left"' (23) have little meaning for the dilemmas and opportunities that confront it. "My ideal intellectual," he states, "may only work in the field of cultural politics, but he or she keeps open the lines of communication with what is happening in other fields, and always reminds himself or herself (and his or her readers and students) that important work is being done elsewhere, and that a 
richly plural democratic polity calls for these varieties of work" (28). Contemporary left politics, it seems, properly operates on many (unnamed) fronts at once, even as university intellectuals might have good reasons, personal and professional, for continuing to devote the bulk of their energies to decoding cultural texts and publishing academic papers.

McGowan positively exalts in his good fortune at landing a tenured position at a research university (he is professor of English and Comparative Literature at the University of North Carolina). "What strikes me," he says, reasonably enough, "is not that the market undervalues our work, but that it values it at all - and consistently at a price above the median paid to all workers ... what I do feels so little like work as I understood that burden when growing up that I am amazed I get paid to do it" (118). He also gets a kick out of academic meetings, such as the Modern Language Association's (MLA) annual convention, where he can listen in on panels sponsored by "the Freudians or the Marxists or the phenomenologists" and reassure himself that they are in fact "still asking the same questions and giving the same answers as when I last checked in on them" (37). Many readers will recognize themselves when he compares his behavior at the MLA convention to that of a manic four year old's: "I talk non-stop, hurriedly and mostly incoherently, from dawn until the early hours of the morning ... I am overwhelmed with anxiety about my career and my work.... One year the brief case with all my money and my hotel reservations got left in a cab" (45).

McGowan exhibits a welcome sense of humor, about the academy and about himself, but underneath all the good-natured joshing he seems to take his place in that world very seriously indeed. His essays on the Victorians and modernity, Kenneth Burke and the concept of culture, and the value of a "pragmatist pluralism" are models of refinement and erudition. But they offer the kind of cautiously provisional judgements that a popular colleague who works well on committees might offer. One imagines Mike Gold, or Dwight Macdonald, stumbling across one of McGowan's push-me-pull-you paragraphs (theorist $x$ has a valid point to make, but so does theorist $y$ ), and impatiently flinging the book over his shoulder. In the context of the immense empirical research and hard-won, if splendidly contestable, insights embedded in Progressive Heritage, and especially Exiles from a Future Time and Intellectuals in Action, Democracy's Children seems unbearably slight. 